\title{
Differential expression of EphA5 protein in gastric carcinoma and its clinical significance
}

\author{
WEI ZHANG ${ }^{1}$, XUE WEI $^{2}$, SHUWEI GUO $^{3}$, JIANDONG WANG ${ }^{3}$, JING LIU $^{1}$ and HAI WANG ${ }^{2,4}$ \\ ${ }^{1}$ Department of Pathology, Taixing People's Hospital, Taixing, Jiangsu 225400; \\ ${ }^{2}$ Department of Pathology, Nanjing Medical University, Nanjing, Jiangsu 211166; \\ ${ }^{3}$ Department of Pathology, Jinling Hospital, Nanjing University School of Medicine, \\ Nanjing, Jiangsu 210002; ${ }^{4}$ Center of Pathology and Clinical Laboratory, Sir Run Run Hospital, \\ Nanjing Medical University, Nanjing, Jiangsu 211166, P.R. China
}

Received November 3, 2017; Accepted December 12, 2018

DOI: $10.3892 /$ ol.2019.10167

\begin{abstract}
The aim of the present study was to evaluate ephrin type-A receptor 5 (EphA5) expression and its clinicopathological significance in gastric cancer. Gastric cancer tissues were analyzed by immunohistochemistry. The association between EphA5 expression and clinicopathological parameters, human epidermal growth factor receptor 2 (HER2) status and Ki-67 proliferation index was statistically analyzed. EphA5 expression was detected in all non-tumor gastric epithelia but was differentially expressed among gastric cancer samples. EphA5 was negatively expressed in 30/110 (27.3\%) and positively expressed in 80/110 (72.3\%) samples from patients with gastric cancer. EphA5 expression was significantly associated with Lauren classification $(\mathrm{P}=0.032)$, lymph node metastasis $(\mathrm{P}<0.001)$, HER2 expression $(\mathrm{P}=0.020)$ and $\mathrm{Ki}-67$ expression $(\mathrm{P}=0.005)$. No significant association was determined between EphA5 expression and age, sex, primary location, depth of invasion and Tumor-Node-Metastasis stage. The present data indicated that EphA5 is differentially expressed in gastric cancer. EphA5 may therefore be a potential therapeutic target and may have clinical utility as a marker for lymph node metastasis in gastric cancer.
\end{abstract}

\section{Introduction}

Gastric cancer is the fourth most common cancer type globally and was recorded to be the third highest cause of

Correspondence to: Dr Jing Liu, Department of Pathology, Taixing People's Hospital, 1 Chang Zheng Lu, Taixing, Jiangsu 225400, P.R. China

E-mail: 1j19840227@163.com

Dr Hai Wang, Center of Pathology and Clinical Laboratory, Sir Run Run Hospital, Nanjing Medical University, 109 Long Mian Da Dao, Nanjing, Jiangsu 211166, P.R. China

E-mail: nanjing_pathol@yeah.net

Key words: ephrin type-A receptor 5, gastric cancer, human epidermal growth factor receptor $2, \mathrm{Ki}-67$ cancer-associated mortality in 2015 (1). According to recent data, the incidence rate of and mortality rate of gastric cancer in China in 2015 was 679.1 and 498.0, respectively, per 100,000 of the population (1). Although mortality rates have decreased since 2010, the outcome for patients with advanced stage gastric cancer remains poor, with an estimated relative 5-year survival rate of $30 \%$ (2). Understanding the molecular mechanisms of carcinogenesis and identifying molecular targets for the development of novel treatments is required in order to improve the survival time of patients with gastric cancer.

Although molecular targets have been identified in gastric cancer, only a limited number have been used as diagnostic biomarkers or therapeutic targets within the clinical setting. The human epidermal growth factor receptor-2 protein (HER2) is a member of the epidermal growth factor receptor family of receptor tyrosine kinases $(2,3)$. HER2 overexpression and/or amplification have been determined in invasive breast cancer (3), and in other cancer types, including colon, ovarian, lung and prostate cancer (4). Amplification of the HER2 gene and overexpression of the HER2 protein is observed in $20 \%$ of gastric cancer cases $(3,5)$. A number of clinical trials of varying design are currently investigating the potential of anti-HER 2 therapies in gastric cancer $(2,3)$. A wide range of response rates have been reported in patients with HER2-positive gastric cancer treated with trastuzumab $(6,7)$, and these data prompted the identification of novel genes associated with the diagnosis and treatment of this disease.

The ephrin type-A receptor 5 (EphA5), previously referred to as brain specific kinase or Cek7, was first isolated from adult mouse brain (8). The Eph family of receptors, named due to the first family member being identified in an erythropoietin-producing human hepatocellular carcinoma cell line, is the largest subfamily of receptor protein-tyrosine kinases (4). Eph receptors and the Eph ligands have been implicated in various aspects of development, particularly nervous system patterning (9-11). The Eph receptors and Eph ligands are divided into two subclasses, $\mathrm{A}$ and $\mathrm{B}$, according to their sequence homology, structure and binding affinity (12). Previously, the Ephreceptors and Eph ligands have been determined to be differentially expressed in various human cancer types, including colorectal, lymphoma, prostate, 
ovarian and lung cancer (13-18). Changes in the expression patterns of these receptors and their ligands may be associated with alterations in tumor behavior, including increased invasiveness, metastatic potential and angiogenesis, and consequently these changes may also be associated with poor patient outcome. EphA5 is differentially expressed in breast, prostate, lung, ovarian and colorectal cancer types (18-22). In a previous study, it was determined that EphA5 was expressed in the normal fallopian tube $(100 \%)$, benign epithelial ovarian tumor cases $(100 \%)$ and the majority of ovarian serous borderline tumor cases (76\%) (5). Reduction of EphA5 expression was observed in ovarian serous carcinoma cases (31\%) and was associated with tumor grade and International Federation of Gynecology and Obstetrics stage (21). In the present study, immunohistochemistry (IHC) was performed to evaluate EphA5 protein expression in a set of specimens from patients with gastric cancer. The association of EphA5 expression with clinicopathological parameters was analyzed. To the best of our knowledge, the present study is the first to investigate the role of EphA5 in gastric cancer.

\section{Materials and methods}

Patients and tissue samples. The study group was comprised of 110 consecutive patients with primary gastric adenocarcinomas. All patients underwent surgical resection without prior chemo- or radiotherapy between January 2015 and December 2016 at the Department of Surgery, Taixing People Hospital (Taixing, Jiangsu, China) and Jinling Hospital (Nanjing, Jiangsu, China). Each tumor was classified according to the Tumor-Node-Metastasis (TNM) system of the World Health Organization Classification of Tumors, Pathology and Genetics of Tumors of the Digestive System (23) and Lauren classification (24). Data were acquired with approval from the Ethics Committees of the Taixing People's Hospital and Jinling Hospital. The formalin-fixed, paraffin-embedded samples were retrospectively collected from the Department of Pathology of Taixing People's Hospital and theSir Run Run Hospital (Nanjing, Jiangsu, China). Of the 110 patients, 80 were male and 30 were female. Mean patient age was 65.7 years (range, 43-82 years). Patient details are summarized in Table I.

Hematoxylinand eosin staining. Hematoxylin and eosin staining is the most common staining technique use in routine histology. The technique uses a combination of two dyes, hematoxylin and eosin, for indication of nuclei and cytoplasmic inclusions in clinical specimens. Briefly, the tissue sections were deparaffinized in xylene for $5 \mathrm{~min}$ at room temperature, then the sections were hydrate by passing through decreasing concentrations of alcohol baths and water $(100,90,80$ and $70 \%$ ). The sections were stained in hematoxylin for 3-5 min, washed with water for $5 \mathrm{~min}$ and differentiated in $1 \%$ acid alcohol for $5 \mathrm{~min}$. One percent eosin Y staining was applied for $10 \mathrm{~min}$ prior to washing and dehydrating.

IHC analysis of EphA5, HER2 and Ki-67 protein expression. IHC for EphA5, HER2, and Ki-67 was performed using a previously described protocol (6). In brief, tissue samples were cut into $4-\mu \mathrm{m}$ thick sections. Gastric cancer tissues were prepared on slides and fixed with $95 \%$ ethanol for $1 \mathrm{~min}$. The sections were deparaffinized using xylene, dehydrated by an ethanol gradient $(95,80$ and $70 \%)$ and then rehydrated with deionized water. Antigen retrieval was performed by autoclave treatment $\left(120^{\circ} \mathrm{C}\right.$ for $2 \mathrm{~min}$ in $1 \mathrm{mmol} / 1$ EDTA, $\left.\mathrm{pH} 8.0\right)$. Endogenous peroxidase was quenched with $3 \%$ hydrogen peroxide in methanol. Samples were then blocked with $10 \%$ goat serum (Abcam, Cambridge, UK) for $10 \mathrm{~min}$ at room temperature to prevent nonspecific binding. Incubation with polyclonal antibodies for EphA5 (dilution, 1:400; cat. no. AM7610a; Abgent, Inc., San Diego, CA, USA), HER2 (dilution, 1:100; cat. no. A0485; Dako; Agilent Technologies, Inc., Santa Clara, CA, USA) and a monoclonal antibody for Ki-67 (dilution, 1:100; cat. no. ab15580; Abcam) was performed overnight at $4^{\circ} \mathrm{C}$. Following washing with PBS ( $\mathrm{pH} 7.4$ ), the sections were then incubated with a secondary antibody against rabbit and mouse immunoglobulin (peroxidase-conjugated; Dako; Agilent Technologies, Inc.) for $30 \mathrm{~min}$ at room temperature. Immunoreactivity was visualized using the colorimetric detection reagent 3,3'-diaminobenzidine. Nuclei were counterstained with hematoxylin at room temperature for $40 \mathrm{sec}$. For EphA5 protein detection, PBS was used in place of a primary antibody as the negative control. Results were visualized using an Olympus light microscope (Olympus Corporation, Tokyo, Japan) at x200 magnification.

Evaluation of IHC data. EphA5 protein expression was semi-quantitatively assessed. Tissue specimens were assigned one of four scores according to the intensity of antibody staining ( 0 , none; 1 , weakly positive/weak light yellow; 2 , moderately positive/medium brown-yellow; and 3, strongly positive/dark brown). Staining extent was graded according to the percentage of stained tumor cells and was defined as follows: $0,0 \% ; 1$, $0<\mathrm{n}<25 \% ; 2,25-50 \%$; and 3, $>50 \%$ positively-stained cells. Staining intensity and staining extent values were added together and these final scores were then used to define expression status as follows: 0-2, negative (-); and 3-6, positive (+) (23). HER2 immunostaining was scored according to the system previously reported for gastric cancer (25) and was as follows: 0 (negative), no reactivity or $<10 \%$; $1+$ (negative), faint with partial membrane staining $\geq 10 \% ; 2+$ (positive), weak-to-moderate with complete or basolateral staining $>10 \%$; and $3+$ (positive), moderate-to-strong with complete or basolateral staining $\geq 10 \%$. Ki-67 positive tumor cells demonstrated punctate yellow-brown nuclear staining. High Ki-67 expression was defined as $\geq 14 \%$ positive tumor cell staining. Immunostained specimens were evaluated independently by two pathologists in a blinded manner. Any discrepancies in the scores were resolved by consensus following further evaluation.

Fluorescence in situ hybridization (FISH). FISH was performed to determine the HER2 status of gastric cancer tissue specimens. The test was performed according to the manufacturer's protocol for the HER2 probe (Beijing GP Medical Technologies, Ltd., Beijing, China). The HER2 gene was labeled with Spectrum Orange and the chromosome-17 centromere (CEP17) with Spectrum Green, which is part of the kit from Beijing GP Medical Technology. Two independent observers blinded to the study scored HER 2 and CEP17 labeling from an analysis of 100 nuclei per tissue specimen, and the HER2:CEP17 signal ratio was subsequently calculated. Tissues 
Table I. Association between the expression of EphA5 and clinicopathological parameters.

\begin{tabular}{|c|c|c|c|}
\hline \multirow[b]{2}{*}{ Parameters } & \multicolumn{2}{|c|}{ EphA5 protein expression } & \multirow[b]{2}{*}{ P-value ${ }^{a}$} \\
\hline & $-(n=30)$ & $+(\mathrm{n}=80)$ & \\
\hline Patients, $\%$ & 27.3 & 72.7 & \\
\hline \multicolumn{4}{|l|}{ Age, $n$} \\
\hline$<70$ years & 22 & 48 & 0.266 \\
\hline$\geq 70$ years & 8 & 32 & \\
\hline \multicolumn{4}{|l|}{ Sex, $n$} \\
\hline Female & 6 & 24 & 0.345 \\
\hline Male & 24 & 56 & \\
\hline \multicolumn{4}{|l|}{ Primary location, $\mathrm{n}$} \\
\hline Lower & 22 & 44 & 0.125 \\
\hline Middle or upper & 8 & 36 & \\
\hline \multicolumn{4}{|l|}{ Lauren, n } \\
\hline Intestinal & 8 & 40 & 0.032 \\
\hline Diffuse & 22 & 40 & \\
\hline \multicolumn{4}{|c|}{ Depth of invasion, $n$} \\
\hline $\mathrm{T} 1 / 2$ & 8 & 26 & 0.647 \\
\hline $\mathrm{T} 3 / 4$ & 22 & 54 & \\
\hline \multicolumn{4}{|l|}{ Lymph node, $\mathrm{n}$} \\
\hline N0/1 & 9 & 55 & $<0.001$ \\
\hline $\mathrm{N} 2 / 3$ & 21 & 25 & \\
\hline \multicolumn{4}{|l|}{ TNM stage, $\mathrm{n}$} \\
\hline $\mathrm{I} / \mathrm{II}$ & 9 & 33 & 0.379 \\
\hline III/IV & 21 & 47 & \\
\hline \multicolumn{4}{|l|}{ HER 2, n } \\
\hline Negative & 22 & 74 & 0.020 \\
\hline Positive & 8 & 6 & \\
\hline \multicolumn{4}{|l|}{ Ki-67, n } \\
\hline$<14 \%$ & 6 & 40 & 0.005 \\
\hline$\geq 14 \%$ & 24 & 40 & \\
\hline
\end{tabular}

${ }^{a} \chi^{2}$ test was used. EphA5, ephrin type-A receptor 5; HER2, human epidermal growth factor receptor 2; TNM, Tumor-Node-Metastasis;

were scored as HER2-positive or HER2-negative depending on whether their signal ratio was $\geq 2$ or $<2$, respectively.

Statistical analysis. Statistical analysis was performed using SPSS version 17.0 for Windows (SPSS Inc., Chicago, IL, USA). The $\chi^{2}$ test was used to analyze the association of EphA5 protein expression with clinicopathological parameters. The data are presented as the mean \pm standard error of the mean. A total of 10 high-power fields (x400) were used for microscopy. $\mathrm{P}<0.05$ was considered to indicate a statistically significant difference.

\section{Results}

EphA5 expression in gastric carcinoma samples. IHC was performed to evaluate EphA5 protein expression in tumor
Table II. Human epidermal growth factor receptor 2 status in gastric cancer detected by IHC and FISH.

\begin{tabular}{lllll}
\hline & \multicolumn{4}{c}{ IHC score (24) } \\
\cline { 2 - 5 } Parameter & 0 & $1+$ & $2+$ & $3+$ \\
\hline FISH-negative & 9 & 6 & 1 & 0 \\
FISH-positive & 0 & 0 & 4 & 9 \\
Total no. & 9 & 6 & 5 & 9 \\
\hline
\end{tabular}

FISH, fluorescence in situ hybridization; IHC, immunohistochemistry.

tissue specimens obtained from 110 consecutive patients with primary gastric adenocarcinoma. EphA5 protein staining was predominantly located in the cytoplasm and weakly stained in the nucleus. EphA5 was positively expressed in all non-tumor gastric epithelia and differentially expressed among gastric cancer tissue samples (Fig. 1). EphA5 was negatively expressed in $30 / 110(27.3 \%)$ and positively expressed in 80/110 (72.7\%) patient specimens.

Association of EphA5 expression with clinicopathological parameters. The association between EphA5 expression and clinicopathological parameters was statistically analyzed (Table I). EphA5 expression was significantly associated with Lauren classification $(\mathrm{P}=0.032)$, lymph node metastasis $(\mathrm{P}<0.001)$, HER2 expression $(\mathrm{P}=0.020)$ and Ki-67 expression $(\mathrm{P}=0.005)$. Notably, EphA5 expression was negatively associated with HER 2 expression and $\mathrm{Ki}-67$ index in the gastric cancer tissues (Figs. 2 and 3). No significant association was determined between EphA5 expression and age, sex, primary location, depth of invasion and TNM stage.

Confirmation of HER2 amplification by FISH. HER2 status in gastric cancer specimens was confirmed by FISH analysis as depicted in Table II and Fig. 4. A total of 96 gastric cancer samples that were HER2-negative (score of 0 or 1+), as determined by IHC, were also negative for HER2 amplification as confirmed by FISH. Out of five samples that had an IHC score of $2+$, four of them demonstrated HER 2 amplification by FISH, and one of these samples exhibited polyploidy. A total of nine samples with an IHC score of 3+ demonstrated HER2 amplification by FISH.

\section{Discussion}

In the present study, the expression of EphA5 in gastric cancer tissues and its association with clinicopathological parameters were examined. EphA5 protein was expressed in all non-tumor gastric epithelia and was differentially expressed among gastric cancer tissue samples. EphA5 was negatively expressed in 30/110 (27.3\%) and positively expressed in 80/110 (72.3\%) samples from patients with gastric cancer. Although the specificity of the anti-EphA5 antibody was confirmed in an ovarian cancer study (21), the absence of a positive control is a limitation of the present study. EphA5 protein expression was reduced in the majority of gastric cancer tissue samples, compared with non-tumor gastric epithelia. Gene 

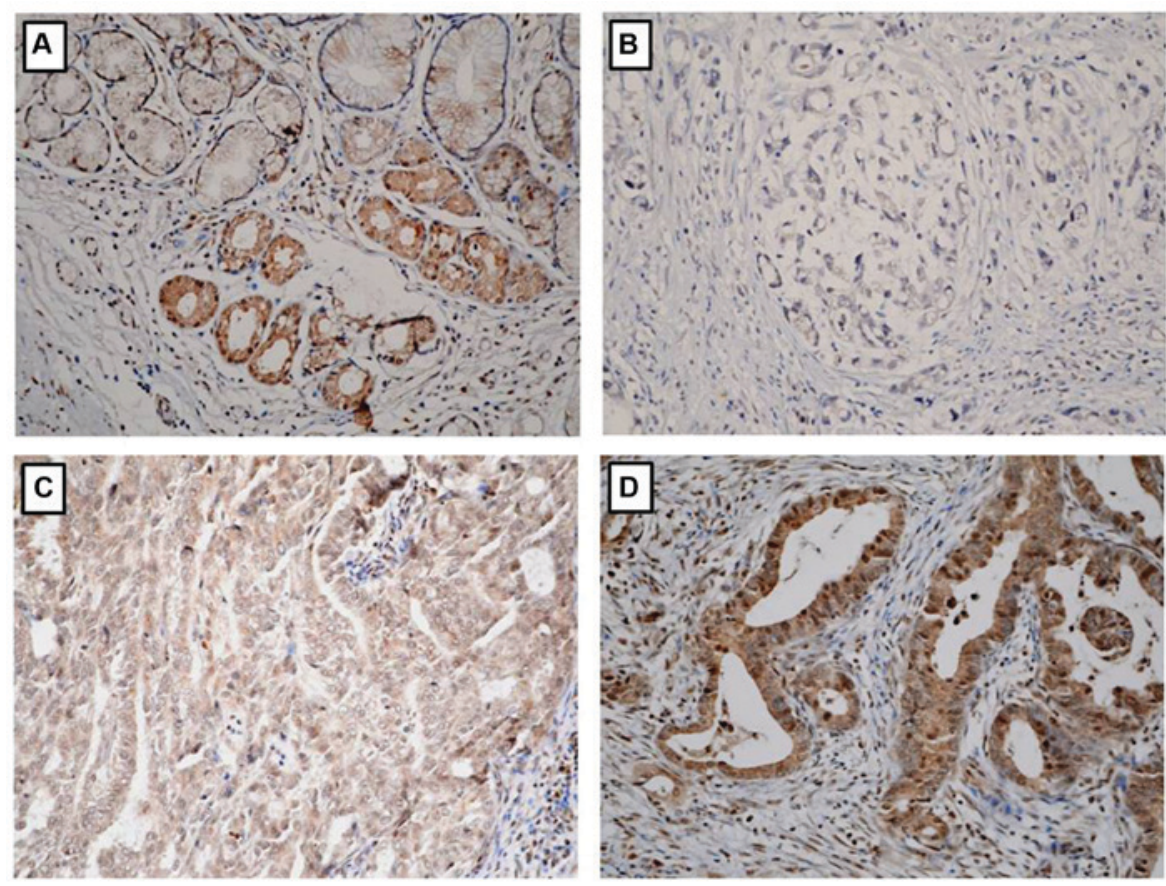

Figure 1. Ephrin type-A receptor 5 expression in non-tumor gastric epithelia and gastric cancer tissues. (A) Positive staining in non-tumor gastric epithelia tissues. (B) Negative expression in gastric cancer tissues. (C) Moderate expression in gastric cancer tissues. (D) Strong expression in gastric cancer tissues. Original magnification, $\mathrm{x} 400$.
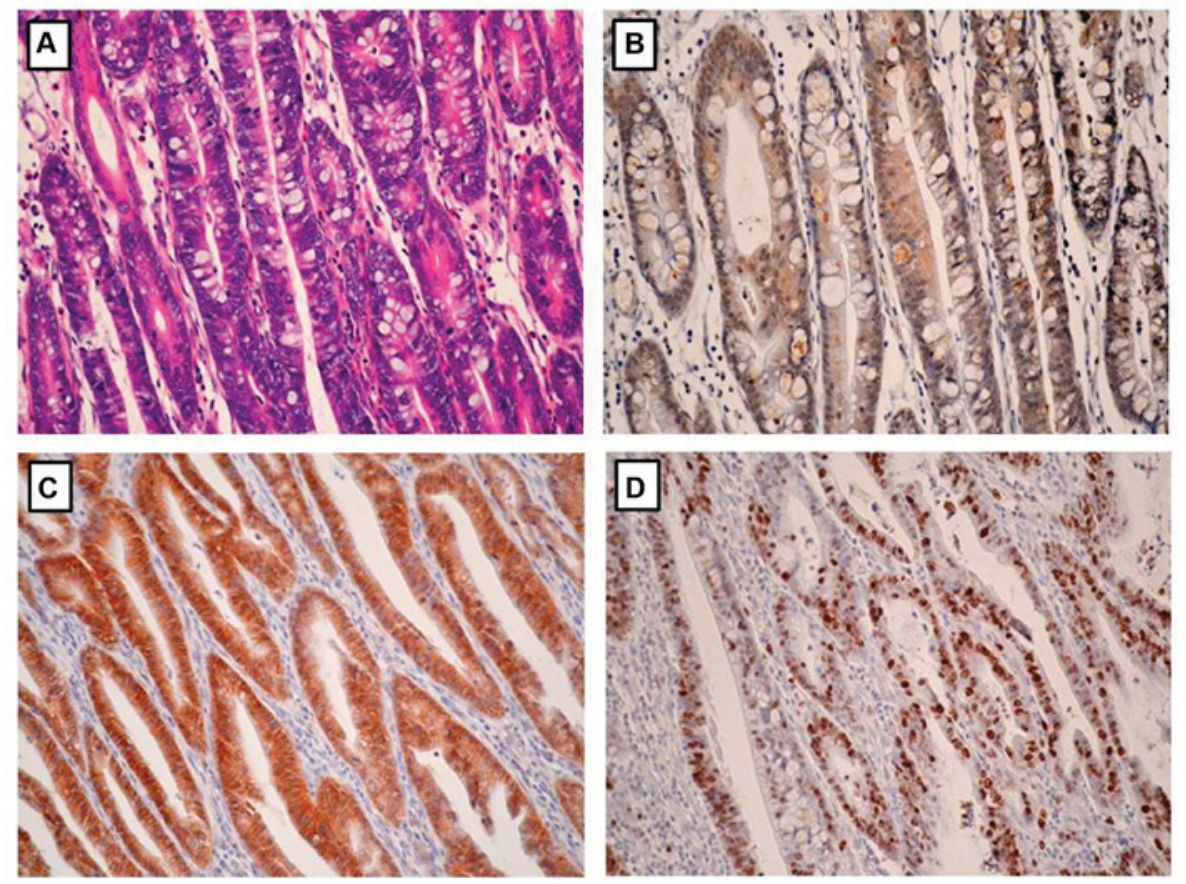

Figure 2. EphA5 expression is negatively associated with HER2 expression and Ki-67 index in gastric cancer tissues. (A) Hematoxylin and eosin staining. (B) Weak EphA5 staining. (C) Strong HER2 staining. (D) High Ki-67 index. Original magnification, x400. HER2, human epidermal growth factor receptor 2; EphA5, ephrin type-A receptor 5.

downregulation in cancer can be attributed to a number of molecular mechanisms, including mutation, deletion, hypermethylation and microRNA regulation. Aberrant methylation of $\mathrm{CpG}$ islands in the promoter region of genes is a frequent mechanism for their downregulation in cancer (26-29).

Hypermethylation of the $\mathrm{CpG}$ island in the EphA5 promoter has been reported in human cancer types (19). EphA5
mRNA expression has been detected in breast cancer cell lines and human breast cancer (19). EphA5 transcripts have been detected in the HBL-100 human breast epithelial galactophore cell line, and the ZR-75-30 and SKBR-3 breast cancer cell lines, while reduction of EphA5 expression has been observed in the MCF-7, T47D, MDA-MB-231, MDA-MB-435S and Bacp37 breast cancer cell lines (19). In primary breast cancer tissues, 

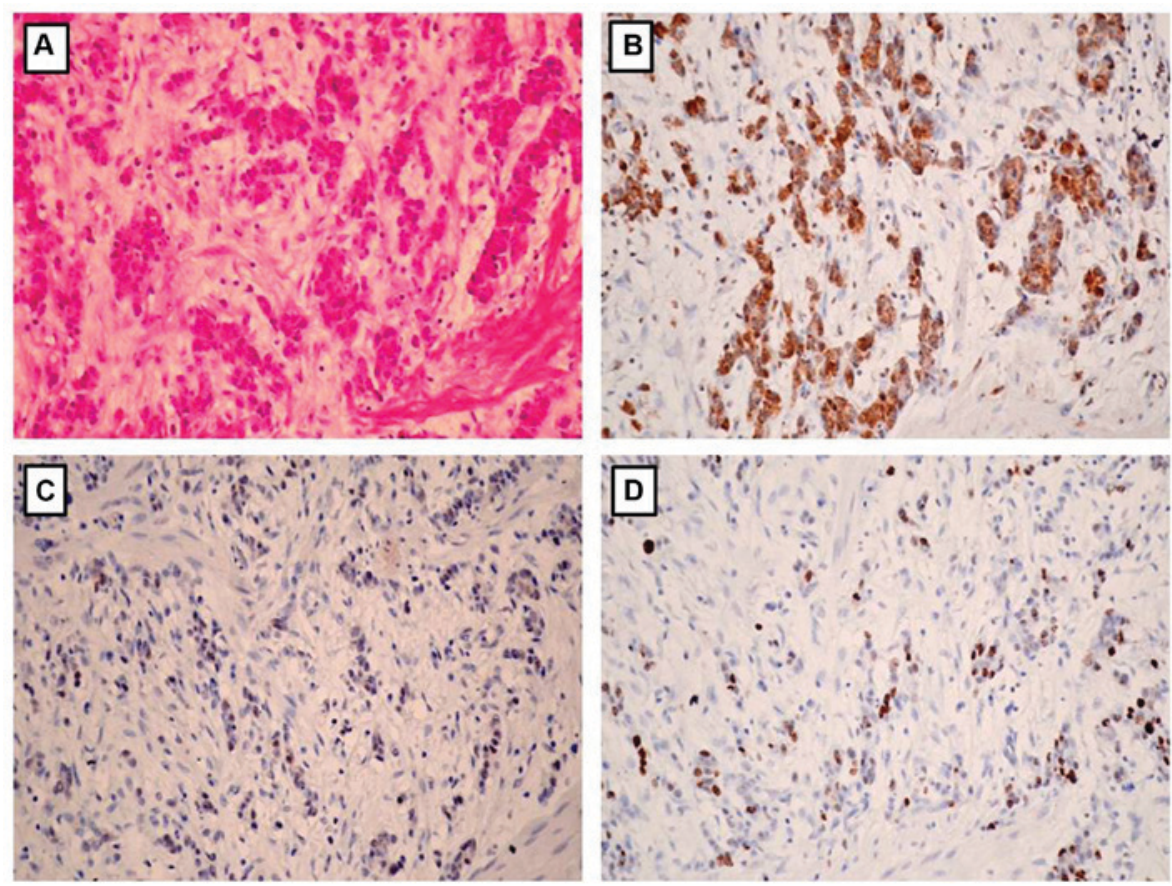

Figure 3. EphA5 expression is negatively associated with HER2 and Ki-67 index in gastric cancer tissues. (A) Hematoxylin and eosin staining. (B) Strong EphA5 staining. (C) Negative HER2 staining. (D) Low Ki-67 index. Original magnification, x400. HER2, human epidermal growth factor receptor 2.
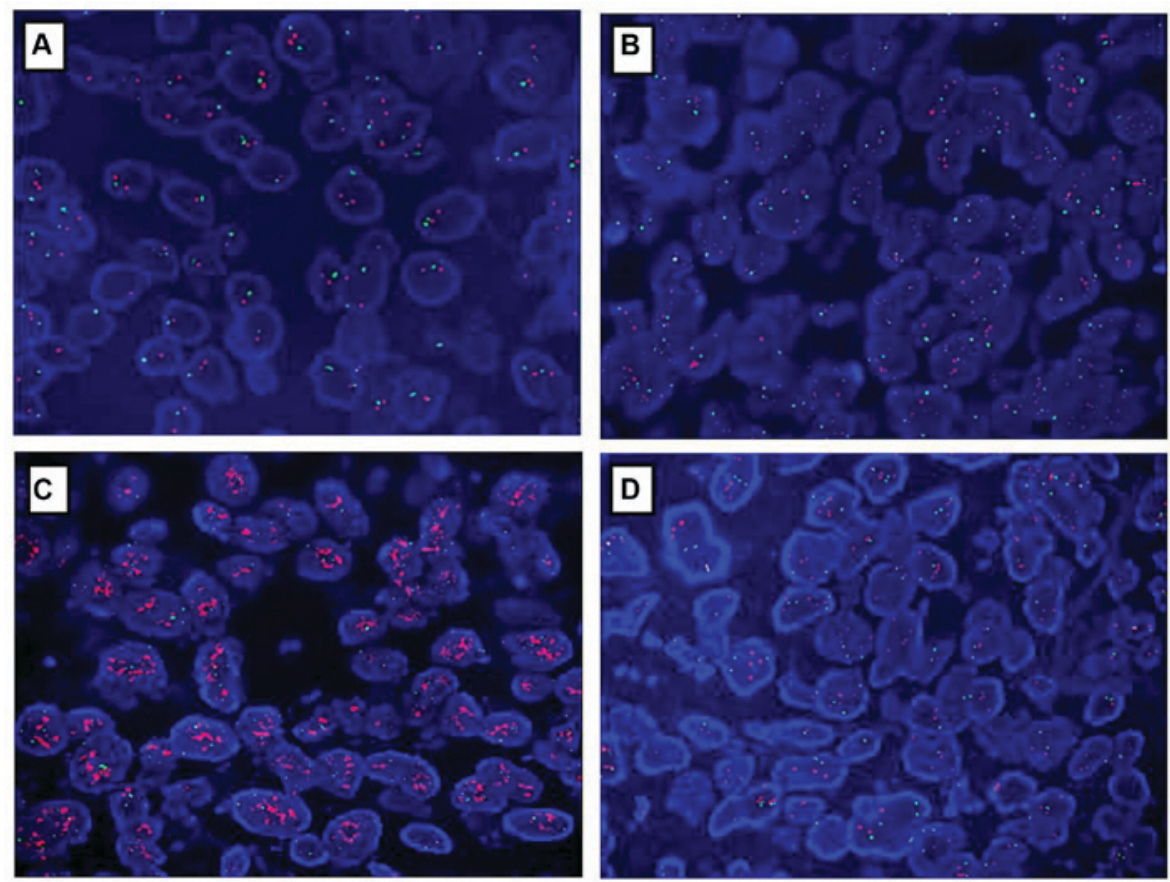

Figure 4. HER2 status of gastric cancer specimens confirmed by fluorescence in situ hybridization. (A) Normal gastric epithelia with two green (chromosome 17 centromere) and two orange signals (HER 2 gene) in each cell. (B) Low HER2 amplification. The orange signals/green signals were between 1 and 2 in each cell. (C) High HER2 amplification. Orange signals/green signals were $>2$ in each cell. (D) Polyploidy. The ratio of orange signals/green signals was $<2$, but orange signals and green signals were $>2$ in each cell. Original magnification, $x 1,000$. HER2, human epidermal growth factor receptor 2 .

EphA5 mRNA levels were determined to be reduced in $67 \%$ of tumor cases, compared with corresponding normal breast tissues. Hypermethylation of the CpG island in the EphA5 promoter was detected in breast cancer cell lines by direct sequencing following bisulfite modification of genomic DNA. Epigenetic silencing of the EphA5 gene was also confirmed in primary breast cancer by methylation-specific polymerase chain reaction (19). Downregulation and promoter hypermethylation of EphA5 have also been observed in human prostate cancer (20). EphA5 expression was negatively detected in $27.3 \%$ and weakly detected in $45.4 \%$ gastric cancer cases. It was determined that hypermethylation of $\mathrm{CpG}$ island in the promoter region of EphA5 is one of the molecular mechanisms. The expression profile in gastric cancer cell lines was not 
checked, based on reports that human cell lines used in China may be contaminated (30), which is a limitation of the present study. In the present study, the methylation status of the $\mathrm{CpG}$ island within the EphA5 promoter region in gastric cancer cell lines and tissues was not examined, which is another limitation of the present study. In future studies, the methylation status of this promoter in gastric cancer tissue samples will be examined and the association between methylation status and clinicopathological parameters will be investigated.

The present data demonstrated that EphA5 expression is associated with Lauren classification and lymph node metastasis. EphA5 expression may therefore have clinical utility as an indicator for lymph node metastasis. HER2 overexpression is increasingly recognized as a frequent molecular event in gastric cancer. The study by Bang et al (2) indicated that the addition of the HER2-targeted agent trastuzumab with chemotherapy significantly improved the survival of patients with HER2-positive metastatic gastric cancer. HER2 expression status is also associated with patient outcome (31). The present data indicated that EphA5 expression is negatively associated with HER2 expression. Notably, a recent study (32) demonstrated that the EphA1/EphA2 signaling axis regulates glutamine metabolism in HER2-positive breast cancer. Future studies are now warranted to elucidate the crosstalk between EphA5 and HER2.

$\mathrm{Ki}-67$ is a nuclear protein associated with proliferation that is an established prognostic biomarker in various human tumor types, including breast cancer, lymphoma and neuroendocrine neoplasia (33-35). Previously, a high Ki-67 index was reported to predict reduced disease-free and overall survival in intestinal-type gastric cancer (35) and advanced gastric cancer (33). In the present study, it was determined that EphA5 expression was inversely associated with the Ki-67 index. The present data indicated that EphA5 may be a molecular marker for gastric cancer metastasis. In the present study, the significance of EphA5 expression in survival was not analyzed due to the tissue specimens analyzed being from patients who underwent surgery recently. In the future, the association between EphA5 expression and survival in gastric cancer will be investigated and its utility in the prognosis of this disease will be evaluated.

In conclusion, EphA5 is differentially expressed in gastric cancer. Downregulation of EphA5 was determined in approximately one third of gastric cancer cases, compared with normal gastric epithelia. Hypermethylation of the CpGisland within the EphA5 promoter provides a possible mechanism for this downregulation. The present data indicated that EphA5 may function as a tumor suppressor in gastric cancer. EphA5 may therefore be a potential therapeutic target and a metastatic marker in gastric cancer.

\section{Acknowledgements}

The authors would like to thank Dr James Monypenny (Biochemistry-Cancer Research UK London Research Institute) for editing the original English grammar within this manuscript.

\section{Funding}

This study was supported in part by the National Natural Science Foundation of China (grant no. 81371611) and the
National Basic Research Priorities Program 973 Project (grant no. 2014CB744501) from the Ministry of Science and Technology of China.

\section{Availability of data and materials}

The datasets used and/or analyzed during the current study are available from the corresponding author on reasonable request.

\section{Authors' contributions}

WZ collected tissue samples. XW conducted FISH. SG conducted IHC. JW analyzed the data. JL designed the project. HW interpreted the data and wrote the manuscript. All authors read and approved the final manuscript.

\section{Ethics approval and consent to participate}

The study was approved by the Ethics Committee of the Taixing People's Hospital (Taixing, China) and Jinling Hospital (Nanjing, China).

\section{Patient consent for publication}

The manuscript was approved by all patients for publication in Oncology Letters.

\section{Competing interests}

The authors declare that they have no competing interests.

\section{References}

1. Chen W, Zheng R, Baade PD, Zhang S, Zeng H, Bray F, Jemal A, Yu XQ and He J: Cancer statistics in China, 2015. CA Cancer J Clin 66: 115-132, 2016.

2. Bang YJ, Van Cutsem E, Feyereislova A, Chung HC, Shen L, Sawaki A, Lordick F, Ohtsu A, Omuro Y, Satoh T, et al: Trastuzumab in combination with chemotherapy versus chemotherapy alone for treatment of HER2-positive advanced gastric or gastro-oesophageal junction cancer (ToGA): A phase 3, open-label, randomised controlled trial. Lancet 376: 687-697, 2010.

3. Szöllösi J, Balázs M, Feuerstein BG, Benz CC and Waldman FM: ERBB-2 (HER2/neu) gene copy number, p185HER-2 overexpression, and intratumor heterogeneity in human breast cancer. Cancer Res 55: 5400-5407, 1995.

4. Ramieri MT, Murari R, Botti C, Pica E, Zotti G and Alo PL: Detection of HER2 amplification using the SISH technique in breast, colon, prostate, lung and ovarian carcinoma. Anticancer Res 30: 1287-1292, 2010.

5. Hofmann M, Stoss O, Shi D, Büttner R, van de Vijver M, Kim W, Ochiai A, Rüschoff J and Henkel T: Assessment of a HER2 scoring system for gastric cancer: Results from a validation study. Histopathology 52: 797-805, 2008.

6. Shitara K, Yatabe Y, Matsuo K, Sugano M, Kondo C, Takahari D, Ura T, Tajika M, Ito S and Muro K: Prognosis of patients with advanced gastric cancer by HER 2 status and trastuzumab treatment. Gastric Cancer 16: 261-267, 2013.

7. An E, Ock CY, Kim TY, Lee KH, Han SW, Im SA, Kim TY, Liao WL, Cecchi F, Blackler A, et al: Quantitative proteomic analysis of HER 2 expression in the selection of gastric cancer patients for trastuzumab treatment. Ann Oncol 28: 110-115, 2017.

8. Zhou R, Copeland TD, Kromer LF and Schulz NT: Isolation and characterization of Bsk, a growth factor receptor-like tyrosine kinase associated with the limbic system. J Neurosci Res 37: 129-143, 1994.

9. Symonds AC, King CE, Bartlett CA, Sauvé Y, Lund RD, Beazley LD, Dunlop SA and Rodger J: EphA5 and ephrin-A2 expression during optic nerve regeneration: A 'two-edged sword'. Eur J Neurosci 25: 744-752, 2007. 
10. Washburn CP, Cooper MA and Zhou R: Expression of the tyrosine kinase receptor EphA5 and its ligand ephrin-A5 during mouse spinal cord development. Neurosci Bull 23: 249-255, 2007.

11. Cooper MA, Crockett DP, Nowakowski RS, Gale NW and Zhou R: Distribution of EphA5 receptor protein in the developing and adult mouse nervous system. J Comp Neurol 514: 310-328, 2009

12. Unified nomenclature for Eph family receptors and their ligands, the ephrins. Eph nomenclature committee. Cell 90: 403-404, 1997.

13. Wang J, Kataoka H, Suzuki M, Sato N, Nakamura R, Tao H, Maruyama K, Isogaki J,Kanaoka S, Ihara M, et al: Downregulation of EphA7 by hypermethylation in colorectal cancer. Oncogene 24: 5637-5647, 2005.

14. Dawson DW, Hong JS, Shen RR, French SW, Troke JJ, Wu YZ, Chen SS, Gui D, Regelson M, Marahrens Y, et al: Global DNA methylation profiling reveals silencing of a secreted form of Epha7 in mouse and human germinal center B-cell lymphomas. Oncogene 26: 4243-4252, 2007.

15. Chen P, Huang Y, Zhang B, Wang Q and Bai P: EphA2 enhances the proliferation and invasion ability of LNCaP prostate cancer cells. Oncol Lett 8: 41-46, 2014.

16. Wang H, Wen J, Wang H, Guo Q, Shi S, Shi Q, Zhou X, Liu Q, Lu G and Wang J: Loss of expression of EphB1 protein in serous carcinoma of ovary associated with metastasis and poor survival. Int J Clin Exp Pathol 7: 313-321, 2013

17. Wu R, Wang H, Wang J, Wang P, Huang F, Xie B, Zhao Y, Li S and Zhou J: EphA3, induced by PC-1/PrLZ, contributes to the malignant progression of prostate cancer. Oncol Rep 32 2657-2665, 2014

18. Staquicini FI, Qian MD, Salameh A, Dobroff AS, Edwards JK, Cimino DF, Moeller BJ, Kelly P, Nunez MI, Tang X, et al: Receptor tyrosine kinase EphA5 is a functional molecular target in human lung cancer. J Biol Chem 290: 7345-7359, 2015

19. Fu DY, Wang ZM, Wang BL, Chen L, Yang WT, Shen ZZ, Huang $W$ and Shao $Z M$ : Frequent epigenetic inactivation of the receptor tyrosine kinase EphA5 by promoter methylation in human breast cancer. Hum Pathol 41: 48-58, 2010.

20. Li S, Zhu Y, Ma C, Qiu Z, Zhang X, Kang Z, Wu Z, Wang H, $\mathrm{Xu} \mathrm{X}$, Zhang $\mathrm{H}$, et al: Downregulation of EphA5 by promoter methylation in human prostate cancer. BMC Cancer 15: 18, 2015

21. Chen X, Wang X, Wei X and Wang J: EphA5 protein, a potential marker for distinguishing histological grade and prognosis in ovarian serous carcinoma. J Ovarian Res 9: 83, 2016.

22. Gu S, Feng J, Jin Q, Wang W and Zhang S: Reduced expression of EphA5 is associated with lymph node metastasis, advanced TNM stage, and poor prognosis in colorectal carcinoma. Histol Histopathol 32: 491-497, 2017.
23. Aaltonen LA and Hamilton SR (eds): Pathology and Genetics of Tumors of the Digestive System. In: The Tumor-Node-Metastasis (TNM) System of the World Health Organization Classification of Tumors. IARC Press, Lyon, 2000.

24. Laurén P: Pekka Laurén and histological classification of gastric carcinoma. Interview and comment by Timo J Nevalainen. Gut 62: 1230-1231, 2013.

25. Woo CG, Ho WJ, Park YS, Park SR, Ryu MH, Jung HY and Kang YK: A potential pitfall in evaluating HER2 immunohistochemistry for gastric signet ring cell carcinomas. Pathology 49: 38-43, 2017.

26. Cabrero M, Yu Y, Verma A, Yang H, Colla S, Jia Y, Zheng H, Bohannan Z, Ganan-Gomez I, Futreal A, et al: Downregulation of protection of telomeres 1 expression in myelodysplastic syndromes with 7q deletion. Br J Haematol 173: 161-165, 2016.

27. Coccaro N, Zagaria A, Orsini P, Anelli L, Tota G, Casieri P, Impera L, Minervini A, Minervini CF, Cumbo C, et al: RARA and RARG gene downregulation associated with EZH2 mutation in acute promyelocytic-like morphology leukemia. Hum Pathol 80: 82-86, 2018.

28. Shuai F, Wang B and Dong S: MicroRNA-204 inhibits the growth and motility of colorectal cancer cells by downregulation of CXCL8. Oncol Res 26: 1295-1305, 2018.

29. Ulker D, Ersoy YE, Gucin Z, Muslumanoglu M and Buyru N Downregulation of SCARA5 may contribute to breast cancer via promoter hypermethylation. Gene 673: 102-106, 2018.

30. Ye F, Chen C, Qin J, Liu J and Zheng C: Genetic profiling reveals an alarming rate of cross-contamination among human cell lines used in China. FASEB J 29: 4268-4272, 2015

31. Chua TC and Merrett ND: Clinicopathologic factors associated with HER2-positive gastric cancer and its impact on survival outcomes-a systematic review. Int J Cancer 130: 2845-2856, 2012.

32. Youngblood VM,KimLC, Edwards DN, Hwang Y,Santapuram PR, Stirdivant SM, Lu P, Ye F, Brantley-Sieders DM and Chen J: The Ephrin-A1/EPHA2 signaling axis regulates glutamine metabolism in HER2-positive breast cancer. Cancer Res 76: 1825-1836, 2016.

33. Huang G, Chen S, Wang D, Wang R, Lin L, Chen S, Wang L and Huang Q: High Ki67 expression has prognostic value in surgically-resected T3 gastric adenocarcinoma. Clin Lab 62: 141-153, 2016.

34. Yagi T, Inoue N, Yanai A, Murase K, Imamura M, Miyagawa Y, Enomoto Y, Nishimukai A, Takatsuka Y, Hirota S, et al: Prognostic significance of geminin expression levels in Ki67-high subset of estrogen receptor-positive and HER2-negative breast cancers. Breast Cancer 23: 224-230, 2016

35. Min KW, Kim DH, Son BK, Kim DH, Kim EK, Seo J, Ahn SB, Jo YJ, Park YS and Ha J: A High Ki67/BCL2 index could predict lower disease-free and overall survival in intestinal-type gastric cancer. Eur Surg Res 58: 158-168, 2017. 